\title{
Petrography and Major Element Geochemistry of Pyroclastics in Afikpo: Tectonic Implications
}

\author{
${ }^{1}$ Okengwu, K.O and ${ }^{2}$ Onwualu-John, J.N \\ Department of Geology, University of Port Harcourt, Port Harcourt, Nigeria
}

\begin{abstract}
Pyroclastics of ultramafic to intermediate compositions (38.83-65.58\% silica) were emplaced in the Asu River Group of Afikpo basins. Petrographic analysis show that the mineral compositions in the rocks are plagioclase, olivine, pyroxene, biotite, and quartz in some of the samples.The pyroclastics plot in the fields of basanite-tephrite, hawaiite and dacite on the total alkaline silica diagram (TAS). The pyroclastics range from silica under saturated to silica saturated and over saturated. These rocks show alkaline to subalkaline affinities. The similarities in pyroclastics of the Afikpo basin are based on their occurrences in the province. The pyroclastics show some transitional features. The basaltic magma seems to have undergone some levels of magmatic differentiation. The magmatic event in the study area has some effects in the sedimentary sequence especially the source rocks (shale) of the study area. The magma that gave rise to the pyroclastics baked most of the organic contents in the shales their by making the source rock to be inactive in petroleum production.
\end{abstract}

Keywords: Pyroclastics, Differentiation, Organic contents, Petroleum production, Afikpo Basin

\section{Introductions}

Benue Trough is a failed arm of triple rift that occurred during the separation of South America from Africa in the Cretaceous age. Southern Benue Trough is a segment of this Benue trough and it has two synclinal basins, Anambra basin in the western flank and Afikpo basin in the eastern flank (Onwualu-John and Ukaegbu, 2009). The sediments in the Benue Trough are estimated to be 6500km thick in some places (Kogbe 1976). The sediments suffered deformations during the Santonian Tectonism. The tectonism in Benue Trough is accompanied by magmatism which led to the emplacement of igneous rocks in the Anambra and Afipo basins. Pyroclastics of ultramafic to intermediate compositions were emplaced on the Afikpo basins during the magmatic episodes. The nature and characteristics of the rocks (pyroclastics) reveal the differentiation mechanisms of the magma. Differentiation is the process by which evolved magma gave rise to rocks of different compositions. Some of the mechanisms involved in the differentiation of magma that gave rise to the pyroclastics are partial melting, crystal fractionation and assimilation. The characteristics of magma depend on the constituent elements in the magma (O'Hara, 1965). Amajor and Ofoegbu (1988) mentioned the occurrence of alkaline pyroclastics in the southern part of the Trough. The pyroclastics in the southern Benue Trough range from alkaline to subalkaline. Onwualu-John and Ukaegbu (2010) documented that there were periods of alkaline magmatism in the southern Benue Trough. Coulon et al (1996) also mentioned about the periods of alkaline and theolitic eruptions of magma in the Benue Trough. The basaltic magma intruded the Asu River Group but due to less viscosity and high mobility of the basaltic magma, the magma was able to crystallize on the surface as pyroclastics in the Afikpo basins. This study is essentially to unravel the differentiation pattern of the magma that gave rise to diversities of pyroclastics in the Afikpo basin.

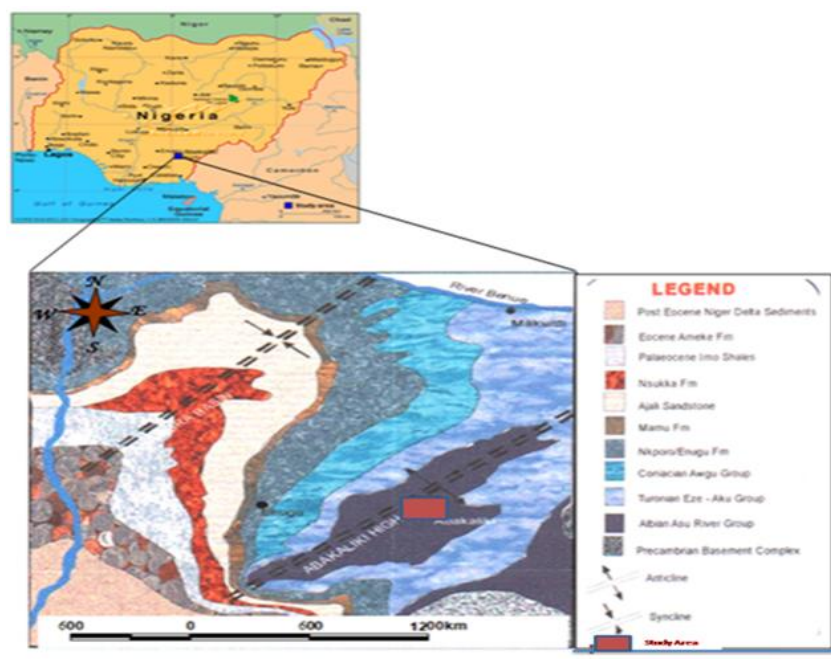


Fig 1: Map showing the study area, retrieved from Google map on 11:09:2015

\section{Geologic Setting}

Southern Benue Trough is a segment of the Benue Trough and Afikpo basin occurs at the eastern flank of the Abakaliki Anticlinorium. The Santonian deformation caused folding and upliftment along NE-SW direction, producing the Abakaliki Anticlinorium with two synclinal basins (Anambra Basin to the NW and Afikpo Syncline to the SE) on the flanks of this folds forming the main depocentres in the post-Santonian times (Onwualu-John and Ukaegbu, 2009).

The rocks in the basin are structurally controlled to the Abakaliki Anticlinorium. The pyroclastics form slightly high relief in the sedimentary sequence of at the Abakaliki -mine 1 and Akpoha quarry while at Abakaliki Ogoja road, the pyroclastics form lenticular relief on the sedimentary sequence. These rocks were emplaced on the Asu River Group which is the oldest sediment in the area.

The field association in the study areas consists of Asu River Group and Eze -Aku shales. The Afikpo basin contains Albian, Turonian - Coniacian and Campanian - Maastrichtian sediments and spans well over $2500 \mathrm{~km}^{2}$ (Odigi and Amajor, 2009).

\section{Sampling Methods}

Twelve representative samples of the pyroclastics were collected from different pockets at AbakalikiMine1, Abakaliki - Ogaja road and Akpoha quarry. The rocks samples were subjected to laboratory analysis which involved thin section preparation and description. In thin section preparation the rock samples were trimmed and polished to reduce the thickness to $0.03 \mathrm{~mm}$ as to allow light to penetrate through during the optical interpretation of the component minerals. The geochemical analyses were carried out at Activation Laboratory Canada, using fusion dissolution method of inductively coupled plasma mass spectrometer (ICP-MS) technique according to Javis and Javis(1992). Interpretation of the geochemical data involves the use of graphs and elemental abundances in the earth crust while the petrography was described using petrological microscope.

\section{Petrology And Petrography}

The pyroclastics in Abakaliki -Mine 1 are of two types. Those that are leucocratic in colour and composed chiefly of consolidated volcanic ash. Their textures are aphinitic. The pyroclastics have average mineral compositions of plagioclase (45\%), plagioclase shows albite twinning, olivine (25\%), olivine shows pale green colour to pleochroic colour of brownish-black, pyroxene (15\%),pyroxene exhibit dark green colour to pleochroic black colour and as well exhibit prismatic cleavage, biotite (7\%), under transmitted light, biotite shows brown to black colour. Biotite exhibit euhedral crystal form. Opaque mineral (3\%) and quartz (5\%) in one of the samples. The second group of pyroclastics in Abakaliki -Mine 1 is greenish in colour with embedded rock fragments. There are consolidated volcanic ash and some volcanic bombs. The average mineral compositions are plagioclase (50\%), olivine (20\%), pyroxene (15\%), biotite (10\%), quartz (3\%), iron ore (2\%).

The pyroclatics in Abakaliki ogoja road are melanocratic in colour, it contain some fragmented rock matrix. The average mineral compositions are plagioclase (45\%), quartz (10\%), pyroxene (15\%), k-spar (20\%), biotite $(8 \%)$

In Akpoha, the pyroclastics are leucocratic and contains some volcanic bombs. The mineral composions are quartz (20\%), pyroxene (25\%), plagioclase (30\%), k-spar (20\%), biotite (4\%)

\section{Major Element Geochemistry}

\section{Geochemistry}

The major element data for the pyroclastics is presented in Table 1 while the illustrative diagrams are presented in Fig 2. Most of the pyroclastics in Abakaliki mine 1 plot in the field of hawaiite, basanit-teprite and one sample on the trachyandesites while the pyroclastics in Akpoha and Abakaliki Ogoja road plot in the dacite field on the $\mathrm{Na}_{2} \mathrm{O}+\mathrm{K}_{2} \mathrm{O}$ vs $\mathrm{SiO}_{2}$ (TAS, total alkaline silica) diagrams of Cox et al. 1979 (Fig 2a). On the $\mathrm{Na}_{2} \mathrm{O}$ $+\mathrm{K}_{2} \mathrm{O}$ vs $\mathrm{SiO}_{2}$ diagrams of Irvine and Baragar, 1971 (Fig 2b), the Abakaliki -Mine 1 pyroclastics plot in the alkaline field while the Abakaliki - Ogoja road and Akpoha pyroclastics plot in the subalkaline field.

Table 1: Major Elements Composition (Wt\%) For pyroclastics in Afikpo basin 


\begin{tabular}{|l|l|l|l|l|l|l|l|l|l|l|l|l|l|}
\hline Samples & Abk1 & Abk2 & Abk3 & Abk4 & Abk5 & Abk6 & Abk7 & Abk8 & Abk9 & Abk10 & Akp 11 & Akp 12 & Av \\
\hline${\mathrm{S} 1 O_{2}}$ & 44.39 & 55.91 & 50.38 & 48.49 & 46.34 & 43.76 & 38.83 & 47.36 & 51.19 & 44.78 & 65.58 & 65.44 & 50.20 \\
\hline $\mathrm{Al}_{2} \mathrm{O}_{3}$ & 16.86 & 19.11 & 17.19 & 16.28 & 18.27 & 16.11 & 17.13 & 16.11 & 13.19 & 15.37 & 13.4 & 13.33 & 16.02 \\
\hline $\mathrm{Fe}_{2} \mathrm{O}_{3}$ & 10.17 & 7.49 & 8.39 & 9.73 & 9.39 & 9.57 & 15.93 & 10.23 & 10.33 & 13.13 & 1.78 & 5.83 & 09.33 \\
\hline $\mathrm{MnO}$ & 0.143 & 0.036 & 0.142 & 0.134 & 0.148 & 0.149 & 0.055 & 0.078 & 0.167 & 0.172 & 0.028 & 0.047 & 00.11 \\
\hline $\mathrm{MgO}$ & 6.51 & 4.63 & 6.48 & 6.28 & 4.82 & 8.07 & 9.48 & 8.1 & 7.82 & 7.89 & 0.52 & 3.08 & 06.14 \\
\hline $\mathrm{CaO}$ & 4.84 & 0.48 & 3.76 & 4.39 & 4.77 & 6.61 & 2.88 & 3.12 & 2.91 & 3.98 & 5.58 & 1.88 & 03.76 \\
\hline $\mathrm{Na}_{2} \mathrm{O}$ & 5.5 & 7.69 & 4.14 & 5.18 & 4.91 & 4.04 & 3.29 & 3.76 & 3.53 & 4.02 & 3.79 & 5.39 & 04.60 \\
\hline $\mathrm{K}_{2} \mathrm{O}$ & 0.2 & 0.04 & 0.03 & 0.07 & 0.07 & 0.02 & 0.02 & 0.03 & 0.04 & 0.06 & 3.22 & 0.06 & 00.32 \\
\hline $\mathrm{TiO}_{2}$ & 2.24 & 0.866 & 2.18 & 2.176 & 1.982 & 2.078 & 3.326 & 2.654 & 2.125 & 2.236 & 0.457 & 1.212 & 01.96 \\
\hline $\mathrm{P}_{2} \mathrm{O}_{5}$ & 0.55 & 0.05 & 0.06 & 0.08 & 0.05 & 0.4 & 0.21 & 0.22 & 0.24 & 0.08 & 0.2 & 0.13 & 00.18 \\
\hline $\mathrm{LOI}$ & 9.2 & 3.86 & 6.45 & 6.86 & 9.1 & 7.82 & 8.37 & 8.25 & 7.88 & 8.1 & 4.81 & 4.16 & 07.07 \\
\hline Total & 100.603 & 100.162 & 99.202 & 99.67 & 99.85 & 98.622 & 99.521 & 99.212 & 99.422 & 99.818 & 99.365 & 10.55 & 99.72 \\
\hline
\end{tabular}

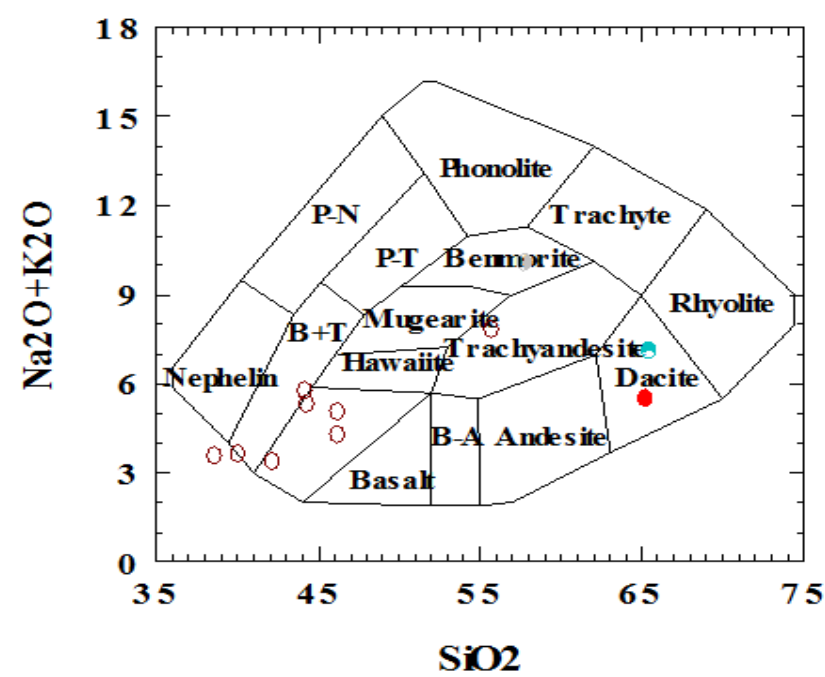

Fig 2a: $\mathrm{Na}_{2} \mathrm{O}+\mathrm{K}_{2} \mathrm{O}$ vs $\mathrm{SiO}_{2}$ diagrams of (Cox et al. 1979$)$ showing the plots of the pyroclastics in the various classification fields, $\mathrm{B}+\mathrm{T}=$ Basanite + tephrite, $\mathrm{Na}_{2} \mathrm{O}=$ sodium Oxide, $\mathrm{K}_{2} \mathrm{O}=$ potassium oxide, $\mathrm{SiO}_{2}=$ silica Oxide

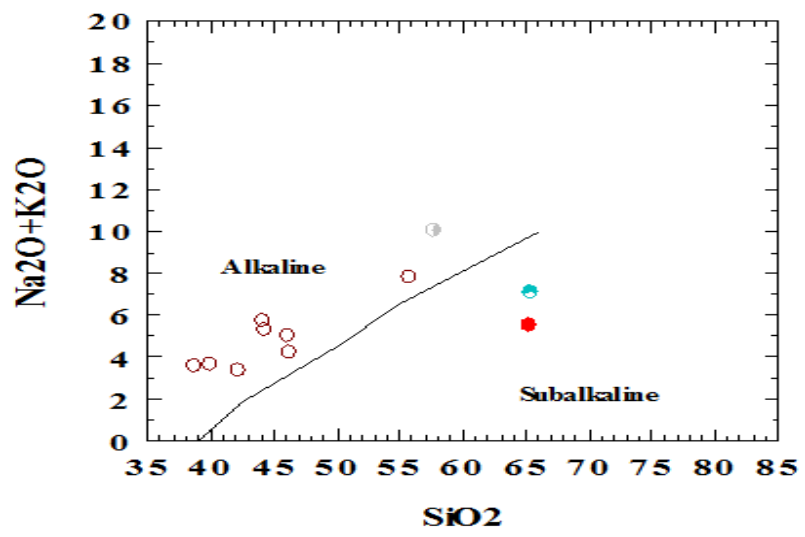

Fig 2b: $\mathrm{Na}_{2} \mathrm{O}+\mathrm{K}_{2} \mathrm{O}$ vs $\mathrm{SiO}_{2}$ binary diagrams shows( Irvine and Baragar, 1971) the plots of the pyroclastics in the various alkaline and subalkaline fields

\section{Discussions}

The variations in the pyroclastics show that they were not products of one episodes of magmatism. The field relations and petrography show that the the pyroclastics in Abakaliki mine 1 are formed at separate magmatic eruption which differs from the magmatic episodes of Pyroclastics at Abakaliki Ogoja road and the pyroclastics at Akpoha quarry. Magma differentiation also played roles in the formation of the pyroclastics in the study area. The plot of the pyroclastics in the B+T, Hawaiite (show the dominance of olivine in the rocks) and trachyandesite field show the extent of the magmatic differentiation on the evolution of the pyroclastics. Trachyandesite field is an indication of the transitional nature of the magma. The physiochemical nature of the Abakaliki mine -1 pyroclastics shows that most of the pyroclastics in the suite crystallized at the early part of magmatic eruption while the differentiating part of the melt were later modified probably by the country rocks on the magmatic channels. The eruption and crystallization of magma on an aqueous/wet sedimentary sequence could initiate assimilation and contamination mechanism into the magma though the characteristics of the rocks depict different episodes of magmatic eruption. Batch melting and progressive eruption probably have played a major role. The pyroclastics of Abakaliki mine 1 are alkaline in nature which indicate the role of alkaline 
magma series in the evolution of the rocks. Mascles et al. (1986) documented that the second magmatic period in Benue Trough was restricted to the Southern Benue Trough, that magmatism of that period is represented by alkaline rocks,

The Pyroclastics in Abakaliki Ogoja road and Akpoha both have similar major element signature, the plot of the pyroclastics in the dacite field could be due to the nature of the erupted magma, the pyroclastics could be product of fractionating magma which have undergone some levels of contamination. They pyroclastics of these areas plot in the subalkaline field which signifies the level of the iron contents in the pyroclastcs of these two zones. The rocks could be products of subalkaline magma series; wet sedimentary environment at the time of the eruption of alkaline magma series can enhance oxidation of the magma thereby making the rocks to be iron rich.

\section{Tectonic Implication}

During the tectonism, the heat of the magma baked most of the organic constituents in the sedimentary sequence (shales). These organic components have the potential of generating petroleum but due to the baking nature of them, they become inactive for petroleum generation. The thermo tectonic events have the capacity of over cooking the organic compounds that will generate petroleum, the degree of the overcooking can give rise to gases.

\section{Conclusion}

The mineral paragenesis shows that the rocks are product of partial melting of the mantle. The physical and chemical features of the pyroclastics support partial melting and progressive eruption of magma. Magmatic differentiation could be the reason for variable geochemical signatures in the rocks which as well has contributed to the nomenclature of the rocks as shown in the total silica -alkaline diagram.

\section{References}

[1]. Amajor, L.C. and Ofoegbu, C.O., (1988). Intra-Continental-Plate Alkaline Basaltic Volcanism, Uturu Southern Benue Trough, Nigeria. Acta Universitatis Carolinae - Geologica, No.2, pp233-242.

[2]. Coulon, C., Vidal, F., Dupuy C., Baudin F., Popoff M., Maluski H., and Hermitte, D., (1996). The Mesozoic to Early Cenozoic Magmatism of the Benue Trough (Nigeria); Geochemical Evidence for the Involvement of the St Helena Plume

[3]. Cox, K. G., Bell, J. D., and Pankhurst, R. J., (1979). The interpretation of igneous rocks. George Allen and Unwin Ltd, London, 450p.

[4]. Irvine, T. N. and Baragar, W. R. A., ( 1971). A guide to the chemical classification of the common volcanic rocks. Canadian Journal of Earth Sciences 8, 523-548.

[5]. Jarvis, I., and Jarvis, K.E., (1992a).Inductively coupled plasma atomic emission spectrometry in exploration geochemistry. Journal of Geochemistry Exploration, 44,139-200.

[6]. Jarvis, I., and Jarvis, K.E., (1992b).Plasma Spectrometry in the earth Sciences: techniques, applications and trends. Chemical Geology, 95, 1-33.

[7]. Kogbe, C. A. (1976). The Cretaceous and Palaeogene sediments of southern Nigeria. In Geology of Nigeria,C.A. Kogbe (ed.).Lagos: Elizabeth publishing Co

[8]. Mascle, J.; Marhino,M. and Wanesson, J. (1986). The Structure of the Guinea continental margin: implication for the connection betweenthe central and the South Atlantic oceans. Geologische Rundschau 75, 57-70

[9]. O'Hara, M.J., (1965). Importance of the 'shape' of the melting regime during partial melting of the mantle. Nature, 314, 58-62.

[10]. Odigi, M. I and Amajor, L. C. (2009), Brittle Deformation in the Afikpo Basin, Southern Nigeria: Evidence for a Terminal Cretaceous extensional regime in the Lower Benue Trough, Nigeria. China. J. Geochem, 28, 369-376

[11]. Onwualu -John, J.N and Ukaegbu, V.U. (2009).Geochemistry of the association of syenodiorites and pyroclastics in the Southern Benue Trough, Nigeria: Petrogenetic and Tectonic implications. World Journal of Applied Science and Technology, Vol 1. No1. pp $11-27$

[12]. Onwualu -John, J.N and Ukaegbu, V.U. (2010), Alkaline Magmatism in the Lower Benue Trough, Southeastern Nigeria: A Geochemical Evaluation. The IUP Journal of Sciences, Vol 4. No.4.pp 23-48 